\title{
ТЕПЛОВОЕ ПОЛЕ РИЖСКОГО ПЛУТОНА
}

В пределах Западной Латвии и акватории Рижского залива проведены в большом объеме геолого-петрографические и геофизические исследования, в результате которых установлен крупный плутон (Богатиков, Биркис, 1973; Голуб, Иванов, 1974). Его характеризует обширная зона гравитационного минимума, включающая южную часть о-ва Сааремаа, Рижский залив и Курземский п-ов. В магнитном поле плутон выражен пониженными значениями, на фоне которых выделяются положительные аномалии. Бурением на о-ве Сааремаа и в северной части Курземского п-ова выявлены гранит-порфиры рапакиви и граниты рапакиви, а в южной части полуострова - породы габбро-норит-анортозитового комплекса (Богатиков, Биркис, 1973; Кристаллический ..., 1983). До настоящего времени имеется ряд нерешенных вопросов, связанных с глубинным строением и формированием плутона. Геотермические исследования, выполненные на рассматриваемой территории, и их анализ позволяют высказать суждения по этому поводу.

Данные о плотности теплового потока (ТП), характерные для Рижского плутона, сообщались в работе (Цыбуля, Урбан, 1987), где отмечались его низкие значения. К настоящему времени получены дополнительные данные о распределении ТП, дающие возможность выявить некоторые особенности в строении плутона.

Результаты вычисления плотности ТП и их класс точности (Смирнов и др., 1974) приведены в таблице. Теплопроводность силурийских и ордовикских отложений для скважин Овиши 94 и Юркалне 36 определяли на основе теплофизических характеристик пород, полученных по образцам из скв. Вентспилс, а наровских отложений - по образцам из скв. Рагациемс. При вычислении ТП в скв. Пярну 383, 330, 345 (эти скважины расположены за пределами плутона в т. н. Пярнуском глубинном гравитационном минимуме; Кристаллический..., 1983, с. 36 и рис. 5) использовали значения коэффициента теплопроводности пород, измеренные по образцам керна, отобранных непосредственно из названных скважин. На основании этих теплофизических характеристик определяли ТП для скв. Вики 532. Теплопроводность всех вышеуказанных толщ рассчитывали по 40 образцам.

В большинстве скважин (за исключением Валдемарпилс, Калтене и Рагациемс) измерение температуры проводили по всему разрезу осадочного чехла до кристаллического фундамента. При определении ТП было установлено, что величина ТП, вычисленная по силурийским и ордовикским отложениям, выше значений, вычисленных по девонским отложениям. Отмеченная закономерность прослеживается во всех исследуемых скважинах. Поэтому для выяснения площадного распределения плотности ТП в пределах изучаемого района сопоставляли одновременно потоки, полученные как по наровским, пярнуским и кемерским, так и по силурийско-ордовикским отложениям. Тепловой поток, вычисленный по девонским отложениям, выделен отдельно и при расчете средневзвешенного для нижних горизонтов не учитывался (на рисунке эти данные приведены в скобках). Из полученных результатов видно 


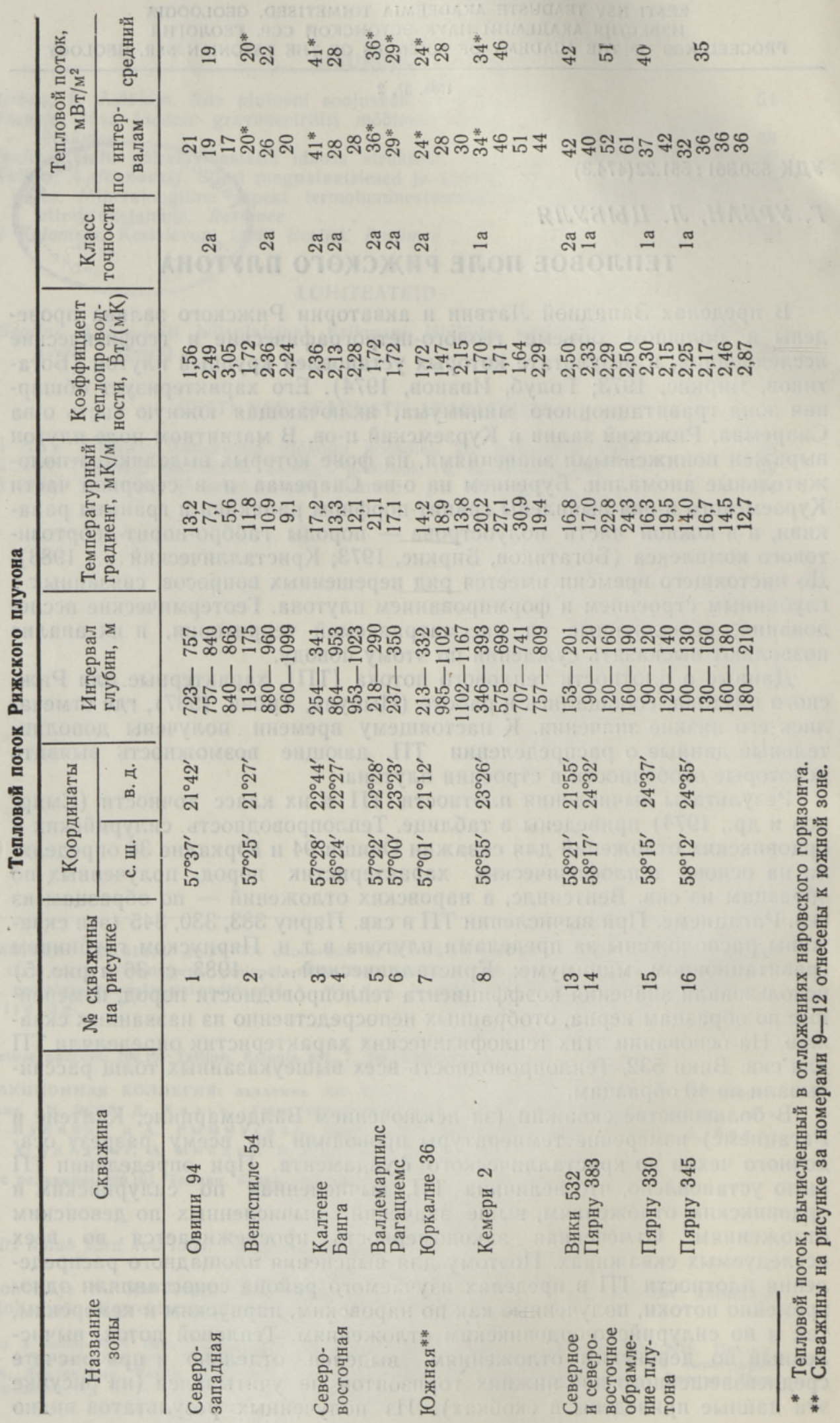


(рисунок), что значения ТП изменяются от 19 до 46 мВт/м². По величине плотности потока в пределах Курземского п-ова можно выделить три зоны: южную, северо-западную и северо-восточную.

Южная зона, верхняя часть фундамента которой представлена породами габбро-норит-анортозитового комплекса, в тепловом поле выделяется несколько повышенной плотностью ТП $(28-38$ мВт/м²), причем отмечается его уменьшение с юга на север.

Северо-западная зона (район скв. Овиши 94, Вентспилс) характеризуется низкими значениями $\left(19-22 \mathrm{мBT} / \mathrm{m}^{2}\right)$.

В северо-восточной зоне наблюдаются повышенные величины теплового поля от 28 до $46 \mathrm{mBT} / \mathrm{m}^{2}$. Увеличение плотности ТП в этой зоне относительно северо-западной отмечается также в результате сравнения значений ТП, вычисленных по отложениям наровского, пярнуского и кемерского горизонтов. Кристаллический фундамент этой зоны, как и предыдущей, сложен гранитами рапакиви.

Установленная неоднородность теплового поля рассматриваемой части Рижского плутона обусловлена неравномерным распределением радиогенных источников тепла, которые в свою очередь зависят от состава пород, слагающих земную кору. В пределах исследуемой территории для пород фундамента имеются лишь единичные определения содержания радиоактивных элементов. Поэтому для суждения о их площадном распределении привлекались данные гамма-каротажа, а также радиогеологические материалы по исследованиям аналогичных пород


Тепловой поток Рижского плутона (тектоническая схема по О. А. Богатикову, А. П. Бнркису (1973); Кристаллическнй ..., 1983).

1 - граниты рапакиви, 2 - габбро-анортозиты, 3 - граница Рижского плутона, 4 разломы: $a-$ доплатформенного этапа развития, $6-$ платформенные; 5 - граннца Пярнуского глубинного минимума; 6 - местоположение скважнн: в числителе - номер скважины, в знаменателе - плотность теплового потока, мВт/м²; с скобках приведены значения, вычнсленные по девонским отложенням. 
Коростенского плутона. Породы габбро-анортозитовой формации Коростенского плутона содержат урана $0,2-1,7$, тория $2,0-4,5$ г/т, торийурановое соотношение не более 3,5 , а граниты рапакиви - урана 2,6 5,8 , тория $20,0-26,3$ г/т, торий-урановое соотношение изменяется от $4,4-4,5$ до 7,7 (Герасимов, 1978). Граниты рапакиви северо-западной зоны Рижского плутона содержат урана 4,0 , тория 3,0 г/т. Для них характерно повышенное значение гамма-активности $(2,9-4,3 \mathrm{pA} / \mathrm{kr})$ по сравнению с породами габбро-анортозитового комплекса $(1,7-2,2 \mathrm{pA} / \mathrm{kr})$.

В ряде работ (Голуб, Иванов, 1974; Анортозит-рапакивигранитная..., 1978; Кристаллический ..., 1983) указывается, что северной части плутона соответствует обширный гравитационный минимум, достигающий наибольшей интенсивности над акваторией Рижского залива. О величине потока в пределах этой части плутона можно судить лишь по измерениям, проведенным на восточном побережье Курземского п-ова (северовосточная зона), где отмечается повышенная плотность ТП. Исходя из геологических построений, принятых для Коростенского и Выборгского плутонов (Анортозит-рапакивигранитная..,, 1978), мы можем предположить, что рассматриваемый гравитационный минимум Рижского плутона обусловлен пластиной гранитов рапакиви мощностью примерно 5 км, ниже которой залегает 20-километровая толща переслаивающихся между собой основных и кислых пород. Исходя из приведенного выше содержания радиоактивных элементов была определена теплогенерация каждого слоя. Для гранитов рапакиви она равна 2,65, а для основных пород - 0,41 мкВт/м³. Если предположить, что из 5-километровой пластины гранитов рапакиви ТП равен 13, а из кровли базальтового слоя $-20,0 \mathrm{mBT} / \mathrm{M}^{2}$, то для компенсации оставшегося ТП необходимо в 20-километровой толще около $15-20 \%$ кислых пород.

Как уже указывалось, гравитационный минимум охватывает часть архейской рамы плутона на восточном побережье Рижского залива. Некоторые авторы (Кристаллический .., 1983) выделяют его как Пярнуский минимум (рисунок), природу которого объясняют глубинными частями плутона, не выходящими на поверхность фундамента.

В этом районе верхняя часть фундамента представлена архейскими гнейсами, обладающими низкой теплогенерацией. Определение радиоактивных элементов в скв. Пуйкуле и Стайцеле (№ 1817) показало содержание урана $<1,2$, а тория от $<3,6$ до 5,8 г/т. Значение плотности ТП в пределах минимума колеблется от 33 до $51 \mathrm{mBT} / \mathrm{m}^{2}$. Для компенсации указанной величины следует предположить существование на глубине пород с более высоким содержанием радиоактивных элементов, которыми могут быть граниты рапакиви.

Низкий ТП в пределах северо-западной зоны на Курземском п-ове свидетельствует об очень малой мощности гранитов рапакиви, залегающих на древних архейских породах. В пользу этого представления говорит наличие здесь положительной аномалии магнитного поля. Незначительное содержание радиоактивных элементов нижележащих пород обусловлено, вероятно, эндогенными и экзогенными процессами, происходившими до эпохи внедрения плутона, которые привели к эрозии верхнего термоактивного слоя земной коры.

В тепловом поле южная зона занимает по величине плотности ТП промежуточное значение между северо-западной и северо-восточной. Она характеризуется отрицательным, небольшим по интенсивности магнитным и слабоположительным гравитационным полями, которые обусловлены различным строением земной коры по отношению к северной части плутона (Анортозит-рапакивигранитная..., 1978).

Выше уже упоминалось, что для пород габбро-норит-анортозитового комплекса характерны низкие значения гамма-активности $(1,7-$ $2,2 \mathrm{pA} / \mathrm{kr})$. Следовательно, наблюдаемое увеличение потока в рассмат- 
риваемой зоне до 38 мВт/м² указывает на то, что нижележащие породы должны обладать повышенной генерацией радиогенного тепла.

Таким образом, на основании изложенного можно сделать вывод, что изменение ТП с запада на восток в северной части Рижского плутона связано с соответственным увеличением мощности гранитов рапакиви. Предполагаемые древние архейские породы северо-западной зоны обладают очень низкой теплогенерацией. Это, вероятно, обусловлено тем, что в предшествующий формированию плутона период они подвергались эрозии, которая привела к уничтожению верхних слоев с более высоким содержанием урана и тория. Отмечающееся увеличение плотности потока на восточном побережье Курземского п-ова вызвано, наряду с увеличением мощности гранитов рапакиви, присутствием в более глубоких слоях земной коры прослоев пород кислого состава. Повышенная плотность потока в южной части плутона вызвана, по-видимому, процессами ультраметаморфизма, имевшими место при формировании габбро-ноританортозитового комплекса (Богатиков, Биркис, 1973).

Величина плотности ТП в пределах Рижского плутона вполне сравнима со значениями потока, полученными для других плутонов. На территории Финляндии плотность ТП для Ботнического и Выборгского плутонов равна соответственно $44-50$ и 34 мВ/м² (Ярвимяки, Пуранен, $1982)$, а на территории Польши для мазурских гранитов $33 \mathrm{mBт} / \mathrm{m}^{2}$ (Майорович, Плева, 1982). Мостовские граниты (Белорусская ССР), которые относят к гранитам типа рапакиви (Пап, 1976), в тепловом поле Белорусской антеклизы выделяются несколько повышенными значениями. Плотность ТП, установленная в этом районе, изменяется от 41 до 48 мВт/м² (Цыбуля, Жук, 1985).

Следовательно, можно отметить, что для плутонов Восточно-Европейской платформы, сложенных гранитами рапакиви, характерен практически одинаковый по величине ТП. Приведенные результаты позволяют предположить, что земная кора под плутонами имеет сходное строение, а также то, что плутоны сформированы близкой по составу магмой.

\section{ЛИТЕРАТУРА}

Анортозит-рапакивигранитная формация. Восточно-Европейская платформа. Л., 1978. Богатиков О. А., Биркис А. П. Магматизм Западной Латвин. М., 1973.

Герасимов Ю. Г. Радиогеохимическая специализация тектонических блоков Украинского щита. - В кн.: Проблемы геологического строения, петрологии и металлогении кристаллического фундамента Белоруссии и смежных районов. Минск, 1978, 103-109.

Голуб Д. П., Нванов М. М. Некоторые геологические результаты изучения магнитного поля акватории Балтийского моря. - В кн.: Региональная геология Прибалтики. Рига, 1974, 153-158.

Кристаллический фундамент Эстонни. М., 1983.

Майорович Я., Плева С. Изучение теплового потока в Польше и решение тектонофизических задач. - В кн.: Тепловое поле Европы. М., 1982, 261-276.

Пап A. М. Главные черты геологического строения, формационный анализ метаморфических и магматических образований докембрия БССР и особенности их метаморфизма. - В кн.: Геология, петрология и металлогения кристаллических

образованнй Восточно-Европейской платформы. М., 1976, 51-58.
Смирнов Я. Б., Безроднов В. Д., Волубуев Г. П. и др. - В кн.: Глубинный тепловой поток Европейской части СССР. Киев, 1974, 7-46.

Цыбуля Л. А., Жук М. С. Тепловой поток Белорусской антеклизы. - Докл. АН БССР, 1985, 29, № 6, 731-734.

Цыбуля Л. А., Урбан Г. И. Тепловое поле Балтийской синеклизы и некоторые аспекты его связи с глубинным строением земной коры. - В кн.: Комплексные исследования глубинного строения территорни Белоруссии и смежных областей. Мннск, 1987 (в печати).

Ярвимяки П., Пуранен М. Измерения теплового потока в Финляндии. - В кн.: Тепловое поле Европы. М., 1982, 322-330, 


\section{RIIA PLUTOONI SOOJUSVÄLI}

Sügavpuuraukudes mõõdeti soojusvoogu Riia rabakivi- ja anortosiidiplutooni ning selle pōhja- ning kirdeäärise kohal. Laboratoorselt uuriti aluskorrakivimite radioaktiivsust ja sellest tulenevat soojustekkevõimet, samuti pealiskorra settekivimite soojusfüüsikalisi omadusi. Soojusvoo intensiivsuse pōhjal saab Kuramaa poolsaarel eraldada kolm vöödet. Kogutud andmete alusel on käsitletud maakoore ehitust Riia plutooni ja selle kirdeäärise alal. Tulemusi on võrreldud Ida-Euroopa platvormi teiste rabakiviplutoonide kohta avaldatud andmetega.

\section{G. URBAN, L. TSYBULYA}

\section{THERMAL FIELD OF THE RIGA PLUTON}

The thermal flow above the Riga Rapakivi and Anorthosite Pluton area and above its north and northeast border was measured in deep wells. Radioactivity and the resulting radioactive heat generation of basement rocks as well as the thermophysical properties of sedimentary rocks at the platform cover were analyzed at the laboratory. In Kuramaa Peninsula three belts of different intensity of the thermal flow have been distinguished. On the basis of the acquired data the structure of the Earth's crust in the area of the Riga Pluton and its northeast border has been discussed. The results obtained are compared with the previously published data on other rapakiviplutons of the East European Platform. 